\title{
Urban Stormwater Management, a Tool for Adapting to Climate Change: From Risk to Resource
}

\author{
María Hernández-Hernández ${ }^{1}\left[\right.$, Jorge Olcina ${ }^{1}\left[\right.$ and Álvaro-Francisco Morote ${ }^{2, *(1)}$ \\ 1 Regional Geographic Analysis and Physical Geography Department, University of Alicante, \\ 03690 San Vicente del Raspeig, Spain; maria.hernandez@ua.es (M.H.-H.); jorge.olcina@ua.es (J.O.) \\ 2 Department of Experimental and Social Sciences Education/Faculty of Teaching Training, \\ University of Valencia, 46010 Valencia, Spain \\ * Correspondence: alvaro.morote@uv.es
}

Received: 24 June 2020; Accepted: 16 September 2020; Published: 18 September 2020

\begin{abstract}
The effects of climate change on rainfall in the Mediterranean region are manifested in an overall decreasing trend, and greater irregularity in annual volumes and the city of Alicante is no exception. In addition, there has also been a spread of the urbanised area, which has led to an increase in the flood risk in urban areas (due to a greater runoff and the occupation of flood hazard areas) and drought events due to an increase in the water demand. In light of these new scenarios, the Mediterranean cities should design adaptation systems based on rainwater harvesting within the framework of a circular economy. This study analyses the integration of rainwater in flood and water demand management in the city of Alicante (Southern Spain). In recent years, this city has developed infrastructures in order to use these resources. To do this, different databases have been analysed (rainfall and volume of water collected in the green infrastructure systems). The results reveal that stormwater has become highly important in urban water management in Alicante as the city is now using a resource that previously went to waste and created problems (flooding and pollution). By way of conclusion, it is worth mentioning that the incorporation of rainwater for urban use in Alicante has reduced the pressure on traditional resources in satisfying water demand and has also acted as a measure for adapting to climate change.
\end{abstract}

Keywords: rainwater; climate change; resource; circular economy; flooding; drought; Alicante

\section{Introduction}

The use of rainwater is a traditional technique based on collecting rainfall and was historically used in the Mediterranean and other semi-arid territories [1]. In traditional societies where agriculture formed the basis of the economy, land and water were highly important. Therefore, when the environment did not provide a sufficient level of these resources, attempting to compensate certain resources with others was the maxim guiding the anthropogenic activities in these semi-arid territories. These actions can be summarised in a double aptitude: (1) searching for techniques for exploiting rainfall, usually concentrated in a few seasonal episodes; and (2) controlling its erosive capacity and adopting the measures necessary to reduce the runoff coefficients generated in the different riverbeds. In this way, with these techniques, the loss of superficial edaphic horizons was reduced, and an extra source of water was also obtained [2]. Therefore, as confirmed by Palerm [3], a comprehensive and efficient management of local rainfall and that of the immediate vicinity was achieved through dispersed runoffs, favouring agricultural output. This comprehensive management also generated a series of advantages understood in terms of positive externalities. Moltó and Hernández [4] note in this respect that: (1) the aquifers were recharged, as large areas of land were laminated; (2) erosion was reduced, and the retention of sediments was facilitated as the whole of the ploughed space was 
structured in a complex system of terraces that prevented landslides and the loss of soil [5]; and (3) the floods were mitigated as a large part of the flow circulating in the watercourses was distributed among cropland, so the effects of the floods in the lower parts of the territory were reduced.

The abandonment of the rainwater harvesting systems occurred gradually throughout the twentieth century [6]. Hernández et al. [7] associate this disarticulation to factors such as changes in the socio-economic dynamics and the greater availability of water resources. The gradual loss of importance of agricultural activities due to their low productivity gave rise to the urbanisation of the rural space. In Spain, this is related to the increase in population and housing, particularly coinciding with the 1960s-1970s and the latest real estate boom (1997-2007) [8]. In the case of water resources, the technological improvements implemented during the twentieth and twenty-first centuries (exploitation of groundwater, water transfers, and desalination) have enabled larger volumes of water to be made available together with a guaranteed supply [1]. These new contributions have guaranteed a regular volume of water throughout the year, dispensing with the need to depend on the irregular rainfall in this region [9].

Water and urban development have deeply interwoven historical links [10]. Cities have depended on reliable water sources for their urban sprawl while urbanisation has enormously modified local, regional, and even national water cycles [11]. The evident incapacity of the conventional drainage systems to cope with the new urban growth and the circulating flows at peak times given the impermeability of the soil, has given rise to proposals for Sustainable Urban Drainage Systems (SUDs). These systems are based on the adoption of strategies that are more respectful with the environment and the water cycle. Over the last decade, there has been a growing interest in innovative stormwater management practices, thus breaking away from conventional "end of pipe" approaches (based on conveying water offsite to centralised detention facilities) [12]. Innovative strategies, referred to as sustainable urban drainage systems, Low Impact Development (LID) or green infrastructures have, therefore, become popular among practitioners and the public authorities [13].

The objective of these systems is to collect the water, transport, and store it as long as possible in order to slow down its speed and favour its infiltration and, consequently, recharge the aquifers and mitigate floods [14]. They also aim to prevent the degradation of water bodies produced by polluting discharges [15]. It can, therefore, be said, that they seek to recover, wherever possible, the natural water cycle lost after years of modernisation [16]. This is called the sponge city [17], which includes different techniques: (1) systems for capturing stormwater to reduce the hazard and pollution caused by water circulating in urban areas (rainwater harvesting units); (2) improvements in urban sewage and drainage systems to adapt them to the intensities of higher flows; (3) the construction of stormwater storage spaces in the form of recreational areas (floodable parks); and (4) generating more sustainable cities thanks to the construction of "green roofs" and green zones [18].

A recent addition to this approach is Rainwater Harvesting (RWH) and its subsequent use as a non-conventional resource based on the principle of adapting the quality water quality to the requirement of its end use (fit for purpose) [7]. Ecological modernisation processes, mostly due to technological and economic instruments, have limited uncontrolled water consumption and, therefore, they are forcefully reducing the need for more water [19]. The so-called "Demand Management" approach must be assessed within the scope of the broader "Integrated Water Resources Management" (IWRM) in which supply and demand measures are combined to produce efficient mixtures aimed at decreasing the ever growing urban need for freshwater.

RWH has emerged as a new field of sustainable water management, which offers an alternative water supply for at least non-drinking uses [20]. Among all the alternative options to minimise drinking water demand, the RWH system has received the highest level of attention due to its easy collection and reuse potential [21]. These alternative resources have very different characteristics [22]. Some of them (i.e., rainwater harvesting) are millennia-old, while others (i.e., treated wastewater and grey water recycling) have caught on as a result of technological progress [11]. RWH is now increasingly used to manage urban flooding and alleviate water scarcity crises [23]. Urban water systems 
throughout the world suffer from recurring and increasing water scarcity, given demand growth, ageing infrastructure, variability, and uncertainty imposed by climate change. RWH systems represent a promising alternative for increasing the flexibility and robustness of water supply systems [24] and may supply daily non-drinking water for irrigation, toilet flushing, car washing and other uses [25].

The scientific literature related to the use of rainwater points towards a change of paradigm, given that whereas it used to be considered as an environmental risk (floods, pollution, etc.), it has gradually come to be seen as a resource that can be upgraded and exploited [26]. The use of rainwater constitutes an extraordinarily interesting alternative for mitigating the natural scarcity of water resources, and to increase the resilience of these territories to the possible effects that will arise from climate change [27]. The forecast effects of climate change in some regions of the world [28], such as the Mediterranean basin, are already being manifested in temperatures and rainfall patterns $[29,30]$. Within a general context of increasing temperatures and the loss of thermal comfort [31], rainfall have been experiencing significant changes in recent decades that condition the future management of water in economic activities and in urban areas [32]. Three main changes can be observed in the Mediterranean basin, which includes the territories of the eastern coast of the Iberian Peninsula: (1) a decreasing trend in precipitations which is set to worsen according to the different climate change models; (2) an increase in the intensity of rainfall. The number of days of rain is lower, but when it rains, the precipitation has a greater hourly intensity, making it difficult to harvest the water which, instead, generates economic damage and the loss of human lives [33]; and (3) an increase in highly intense drought episodes, although shorter lasting [34]. In short, rainwater in the Mediterranean region has become complex to manage due to the difficulty in controlling its extreme behaviour (reduction in the amount and increase in the hourly intensity) as happens in other areas of the world [35]. This has led, on the one hand, to the need to incorporate climate change forecasts in the water and territorial planning processes on a state and regional level. On the other hand, to implement sustainable drainage systems based on large capacity collectors, rainwater tanks, or green spaces for accumulating water (floodable gardens and parks).

The use of rainwater provides other advantages including: (1) its renewable nature; (2) its collection on a local level, eliminating tension between territories over its use; and (3) its relative ease of access and availability, provided that it is adopted on a domestic level and related to "water harvesting" and sustainable urban drainage strategies [36]. This last point reveals the importance of including a social and political dimension, particularly with respect to the conditions of the water rainfall governance. In this respect, the so-called Urban Political Ecology approach has emerged as a highly interesting theoretical reference for studying the socio-ecological processes that occur in urban and tourism areas, particularly the frameworks of power under which resources such as water are metabolised [7].

The selection of the topic and the area of study are determined by: (1) the notable increase in the urbanised area and the increase in the disarticulation processes of the water cycle [37]; (2) the semi-arid nature of the territory, where heavy rains and drought are features that define the climate of the study area. According to climate change forecasts, these characteristics will become more accentuated; (3) The scarcity of water resources as a result of natural factors but also the increase in demand from the 1970s has given rise to strong pressure on water resources (overexploitation of aquifers, water transfers from other water basins and the incorporation of non-conventional resources, particularly desalination) [38]; (4) the existence of floodable areas where flood defences have been constructed since the mid-1990s in order to mitigate these processes; and (5) the incorporation of rainwater in the water demand management of the city of Alicante, which is recovering abandoned traditional techniques [39].

The objectives of this study are: (1) to confirm the change of rainfall stated by studies as a result of climate change given its impact on the availability of water resources; (2) to examine the incorporation of rainwater in the management of water demand in the city of Alicante (Southern Spain), taking into account its purpose and the volumes stored; and (3) to propose future action for harvesting and using 
rainwater in a scenario of adaptation to climate change. The starting hypothesis is that the use of rainwater in the area of study will intensify in the coming years as a result of climate change in an attempt to minimise the impact that this change will have on the increase of extreme events (droughts and floods).

\section{Materials and Methods}

For this research, data have been drawn from various sources: (1) daily rainfall data (mm/24 h) from the Ciudad Jardin observatory (Alicante) (1980-2019) to establish the increase in the intensity of the rainfall and, indirectly, the greater torrential nature of rainfall; (2) data on the volume of water stored in the Green Infrastructure Systems (NBS) existing in the city of Alicante (2011-2019); and (3) the network of infrastructures for harvesting rainwater. The first source has been provided by the State Meteorology Agency (AEMET) [40] and the Valencian Association of Meteorology (AVAMET) [41]. Rain data accumulated daily are presented since this is the format provided by AEMET. This organism does not supply the rain that is recorded for hours. The second and third sources have been provided by the city's water supply company (Aguas Municipalizadas de Alicante, Empresa Mixta, AMAEM, Alicante, Spain) [42]. This water company is owned in equal parts by the city council and a private company (Hidraqua, Gestión Integral de Aguas de Levante S.A.), a subsidiary of Aquadom (Suez Environment) managing the hydrological cycle. The data provided by AMAEM refer to the monthly volumes of rainwater that have been harvested in the two green infrastructures of the city since their construction. In the case of the Anti-pollution Tank, the series of data are for 2011-2019, while those for the La Marjal Floodplain Park are for 2015-2019. These time series are sufficiently broad so as to enable us to analyse the heavy rain episodes and examine the potential of the rainwater harvested.

The analysis and consulting of primary data has been complemented with secondary sources. First, the rainfall data have been compared with that of other meteorological stations of the Mediterranean coast in order to determine whether the climate behaviour of the city of Alicante is similar to other Spanish Mediterranean cities [43-46] and government body reports (AEMET and CEDEX) [47,48]. Second, the climate modelling carried out for the Spanish case by AEMET has been consulted. This modelling, published in the organisation's portal of climate scenarios, has forecast the evolution of different climate elements in regional areas based on the use of different models [49]. In this way, we are able to determine how climate change will affect rainfall in terms of the increase in its torrentiality and its reduction in frequency (drought). Finally, establishing the layout of the ravines that cross the city using photogrammetric restitution enables us to identify the areas where it would be necessary to build rainwater harvesting units. Comparing this with the main green areas of the city (public parks) such as private gardened areas (outdoor uses of detached houses) enables us to relate the availability of this water to the potential areas for its future use. This has given rise to the proposal of the construction of new infrastructures to harvest rainwater and, on the one hand, reduce the effects of flooding and, on the other, increase the water supply in the city to be used by certain potential areas.

Finally, the preparation of proposals for the storage of rainwater included in this study has been possible by consulting studies on the geographic and hydrological features of the territory [50,51] and observing the urban evolution of the city together with a field research.

\section{Results}

\subsection{Evolution of Rainfall: An Increase in Heavy Rain and an Intensification of Dry Periods?}

The Spanish Mediterranean coast has two climate processes that are highly interesting for water management and territorial planning: (1) an overall downward trend in rainfall, although with territorial nuances [48,52]; and (2) an increase in the hourly intensity of rainfall. The city of Alicante intervenes in both processes, having carried out actions to adapt to the more extreme nature of rainfall with "classic" solutions (construction of desalination plants and channelling of ravines) and "sustainable" solutions (reuse of urban wastewater, rainwater tanks, floodable park). 
Heavy rains have been a constant feature in Alicante and have generated extensive damage, particularly after 1950 [40,53]. The events of October 1982 and September 1997 are particularly noteworthy, which caused severe economic damage and the loss of human lives. In both cases, the accumulated rainfall exceeded $200 \mathrm{~mm}$ in $24 \mathrm{~h}$. However, considering the rainfall regime of the study area, the rains are concentrated in a few hours. For example, in the 1997 episode that collected $270.3 \mathrm{~mm}$. in 30 September, these were mainly recorded in just over $4 \mathrm{~h}$, between 9 and 12 and 15 and $16 \mathrm{~h} \mathrm{[53].} \mathrm{In} \mathrm{the} \mathrm{series} \mathrm{of} \mathrm{relevant} \mathrm{flooding} \mathrm{episodes} \mathrm{occurring} \mathrm{in} \mathrm{the} \mathrm{city} \mathrm{since} \mathrm{the} \mathrm{mid-twentieth}$ century, we can observe that, from 1980 (Table 1), the city has been subject to serious waterlogging and floods of over $50 \mathrm{~mm} / 24 \mathrm{~h}$. The majority of these events are concentrated in the late summer months. In fact, they are really hourly rainfalls with the maximum quantities accumulating in 60-90 min.

Table 1. Episodes of intense rainfall $(>50 \mathrm{~mm} / 24 \mathrm{~h})$ with flooding effects in the city of Alicante (1980-2019).

\begin{tabular}{cc}
\hline Date & Accumulated Rainfall $(\mathbf{m m} / \mathbf{2 4} \mathbf{h})$ \\
\hline 20 October 1982 & $233.1 \mathrm{~mm}$ \\
4 November 1987 & $92.0 \mathrm{~mm}$ \\
5 September 1989 & $133.6 \mathrm{~mm}$ \\
30 September 1997 & $270.3 \mathrm{~mm}$ \\
23 October 2000 & $55.4 \mathrm{~mm}$ \\
21 September 2007 & $90.4 \mathrm{~mm}$ \\
28 September 2009: & $131.0 \mathrm{~mm}$ \\
18 November 2012 & $55.2 \mathrm{~mm}$ \\
19 January 2017 & $66.0 \mathrm{~mm}$ \\
13 March 2017 & $137.4 \mathrm{~mm}$ \\
28 January 2018 & $55.2 \mathrm{~mm}$ \\
21 August 2019 & $86.8 \mathrm{~mm}$ \\
12 September 2019 & $74.6 \mathrm{~mm}$ \\
\hline
\end{tabular}

Source: AEMET [40]. Own elaboration.

Based on the analysis carried out of rainfall episodes recorded in the city of Alicante in the chronological period between 1980 and 2019 and on the classification of "intense" precipitation events (between $20-50 \mathrm{~mm} / 24 \mathrm{~h}$ ) and "torrential" episodes ( $>50 \mathrm{~mm} / 24 \mathrm{~h}$ ), it is possible to identify the following features: (1) the evolution of the episodes of short and intense downpours displays a reduction in number between 1980 and 2006, with a significant spike in the last decade, with 40 rainfall episodes between 20-50 mm recorded; (2) there was a significant drawdown in the episodes of between 50 and $100 \mathrm{~mm}$ during the period 1987-1996. From this decade, there was an increase in the number of these events in the city of Alicante; and (3) for episodes of more intense rainfall ( $>100 \mathrm{~mm} / 24 \mathrm{~h})$, there is not a defined trend.

Two causes explain the increase in these intense rainfall episodes in Alicante: the increase in "gota fría" (cold drop) situations and the increase in the temperatures recorded of the waters of the Mediterranean Sea. Muñoz et al. [54] confirm the increase in cold drop atmospheric situations in mid-latitudes of the earth. They increased by $20 \%$ in the northern hemisphere between 1960 and 2017. A higher frequency of these situations in mid-latitudes and particularly in the Mediterranean basin sector reaffirms the trend towards a greater incidence of intense rain episodes in our study area [55]. The increase in the superficial temperature of the Mediterranean Sea is also clear [56]. It has experienced a warming of its waters throughout the basin, but particularly in the eastern and western edges. With respect to the western side, the data provided by Pastor et al. [57] shows an increase in temperature of $1.2{ }^{\circ} \mathrm{C}$ between 1980 and 2018. This means that the heat accumulated in the water basin is higher than the warming experienced in the air and recorded in the observatories of the Spanish Mediterranean coast. The two processes have favoured a higher number of heavy rainfall episodes in the city of Alicante since the year 2000, which has given rise to the harvesting and use of stormwater in 
recent years in this urban space. The relationship between the changes in rainfall and their possible relationship with changes in the overall atmospheric circulation has been demonstrated.

The city of Alicante rests on a large glacis, which is cleaved by several small water courses (ravines) which have been incorporated into the urban area through historical processes of expansion of the urbanised areas of the city. This incorporation did not take into account the extraordinary rising of the volume of the ravines. So, when rainfall amounts of over $100 \mathrm{~mm} / \mathrm{h}$ are recorded, the water flows recover the former paths, now urbanised, of these watercourses. In this way, the path of these watercourses and their drainage areas mark the principal flood areas of the city of Alicante (Figure 1). From south to north: final stretch of the Ovejas ravine (San Gabriel neighbourhood); the Agustín-San Blas ravine (Santo Domingo neighbourhood and ending sector of Avda. Oscar Espla); Canicia ravine (final stretch in Calderón de la Barca street, Rambla de Méndez Núñez and Bilbao street); Bonhivern ravine (Avenida de Dénia, Sangueta neighbourhood); and the ravines of Orgegia (Vistahermosa) and Juncaret (hamlet of Santa Faz) which in their final stretch configure the Maldo ravine (urban sector of the Albufereta). In addition, there were also the former wetlands (marshes) with precarious drainage that traditionally constituted areas of convergence of the water from abundant rainfalls and which, from the 1950s, began to be urbanised. This is the case of the flooding sectors of the Albufereta beach and the surrounding areas (Colonia Romana) or San Juan beach (Avenue Costablanca).

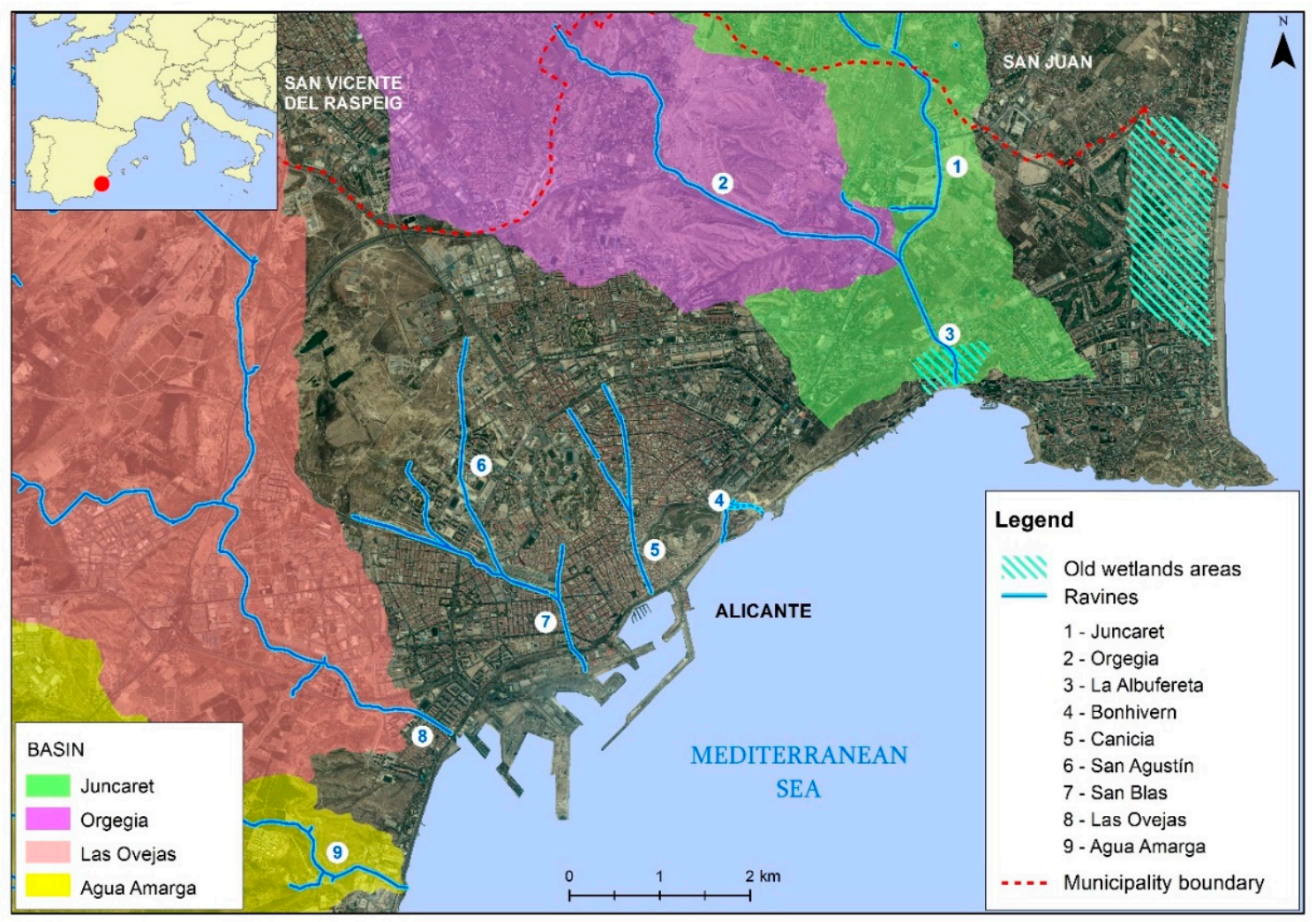

Figure 1. Watercourses and floodable areas incorporated into the city of Alicante. Own elaboration. Note: the ravines $4,5,6$, and 7 , due to urban growth, were incorporated into the urban core through their underground and channelling.

Using stormwater in areas with a semi-arid climate, such as the city of Alicante, fulfils the double objective of reducing the risk of intense flooding events and storing rainwater to use in dry seasons. As previously indicated, there is an overall downward trend in precipitations on the Mediterranean coast and an increasing trend in the number of dry days [28,31]. The evolution of temperatures in the city of Alicante follows the upward trend that is experienced throughout the Spanish Mediterranean coastline. The upward trend is noted both in the daytime maximums and especially in the minimum night 
temperatures, with a very significant increase in the so-called "tropical nights " $\left(\mathrm{T}^{\mathrm{a}} \mathrm{min}>20^{\circ} \mathrm{C}\right)[58]$. The city of Alicante has an average annual rainfall of a little over $300 \mathrm{~mm}$, in the range of BS climates of the Köppen climate classification with a high inter-annual irregularity. Furthermore, it has experienced a significant reduction in this average annual amount $(-12 \%)$ over the last two decades: $357 \mathrm{~mm} / \mathrm{year}$ (1960-1990) to $311 \mathrm{~mm} /$ year (1980-2010) [40]. The record for the lowest annual rainfall in the city of Alicante was recorded in 1995, with barely $108 \mathrm{~mm}$ (Figure 2). However, the drought risk threshold for the area of Alicante can be established at $250 \mathrm{~mm} /$ year [59]. In short, this corresponds to more than 150 days per year with anti-cyclonic situations compared to the 90 days that are, on average, recorded per year [60]. Since 2000, the city of Alicante has recorded a 55\% of years with rainfall below this threshold. It must be highlighted that 2000, 2005 and 2014 recorded values below 200 mm/year (see Figure 2).

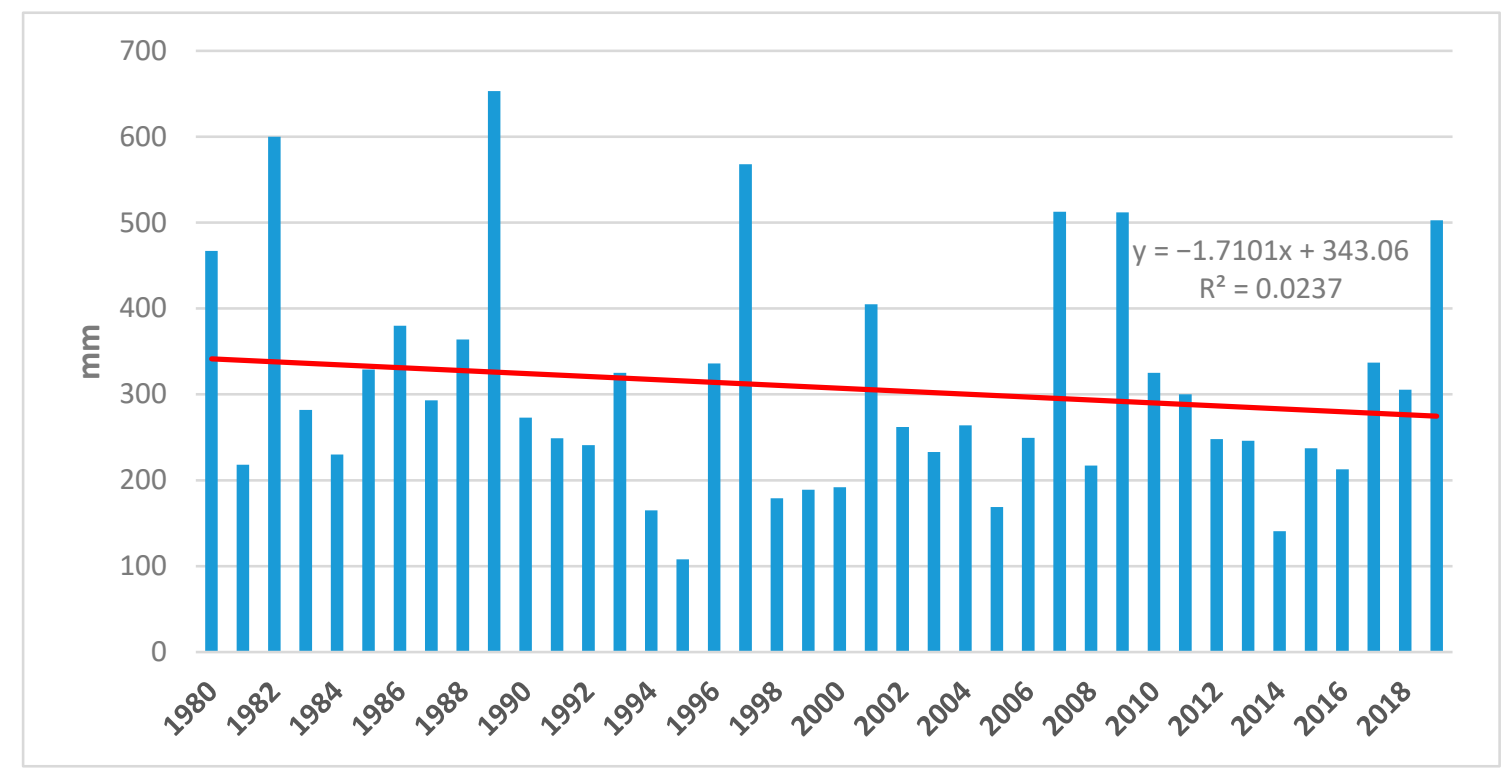

Figure 2. Evolution of the rainfall/year in the city of Alicante (1980-2019). Source: [40]. Own elaboration.

In his study on rainfall in Spain, Serrano [45] notes a significant negative trend in the analysis of the maximum annual rainfall in one day in the Iberian Peninsula, for the period 1950-2012. Serrano's study about the Mediterranean coast, and, particularly, the territory of the south-east of the Iberian Peninsula, finds values with a higher trend in the reduction of the number of days of rain period year in the Spanish peninsula. For Alicante, AEMET [49] indicates a reduction of $10 \%$ in annual rainfall with the horizon of 2100 for RCP 4.5, which increases to up to $20 \%$ in RCP 8.5 scenarios. Meanwhile, the annual number of dry days displays a declining trend of between 5\% (RCP 4.5) and 15\% (RCP 8.5). Similar conclusions are drawn for the area of Alicante in the report on the impact of climate change on water resources and droughts in Spain [48].

\subsection{Changes in the Water Cycle and Rain Harvesting Infrastructures in the City of Alicante}

In the city of Alicante, the company responsible for supplying drinking water (AMAEM) in recent years has been committed to adopting new actions focused on incorporating water resources that had been traditionally ruled out, such as stormwater. The reasons that explain this change in water policy are: (1) the increase in the water demand associated with urban typologies with outdoor uses from the 1990s [61]; (2) the new proposals for water resource management defending the application of different quality waters according to use; (3) the need to minimise the impacts associated with heavy rainfall; and (4) avoiding the discharge of pollutant waters into the sea. In addition to increasing the supply of the resource (once treated), the harvesting and subsequent use of runoff water from rainfall has three environmental aims: 
- To minimise the flood hazard for areas of reiterated risk, given their location in either land-locked areas or close to the sea level (Figure 3).

- To reduce the level of pollution of superficial urban drainage, given the high percentage of lead as a result of vehicle pollution. Also, to mitigate the damage generated by these pollutants being discharged on the beaches with the resulting loss of quality of their waters. Both of these issues are particularly important given the relevance of the sun and beach tourism activity developed in the city.

- To create public green areas for the leisure and entertainment of the citizens, which are so necessary in urban areas. These new spaces have been created, both directly, exploiting these green infrastructures (floodable parks) and, indirectly, having an available resource (stormwater) that increases the water supply for non-consumptive uses (watering gardens).

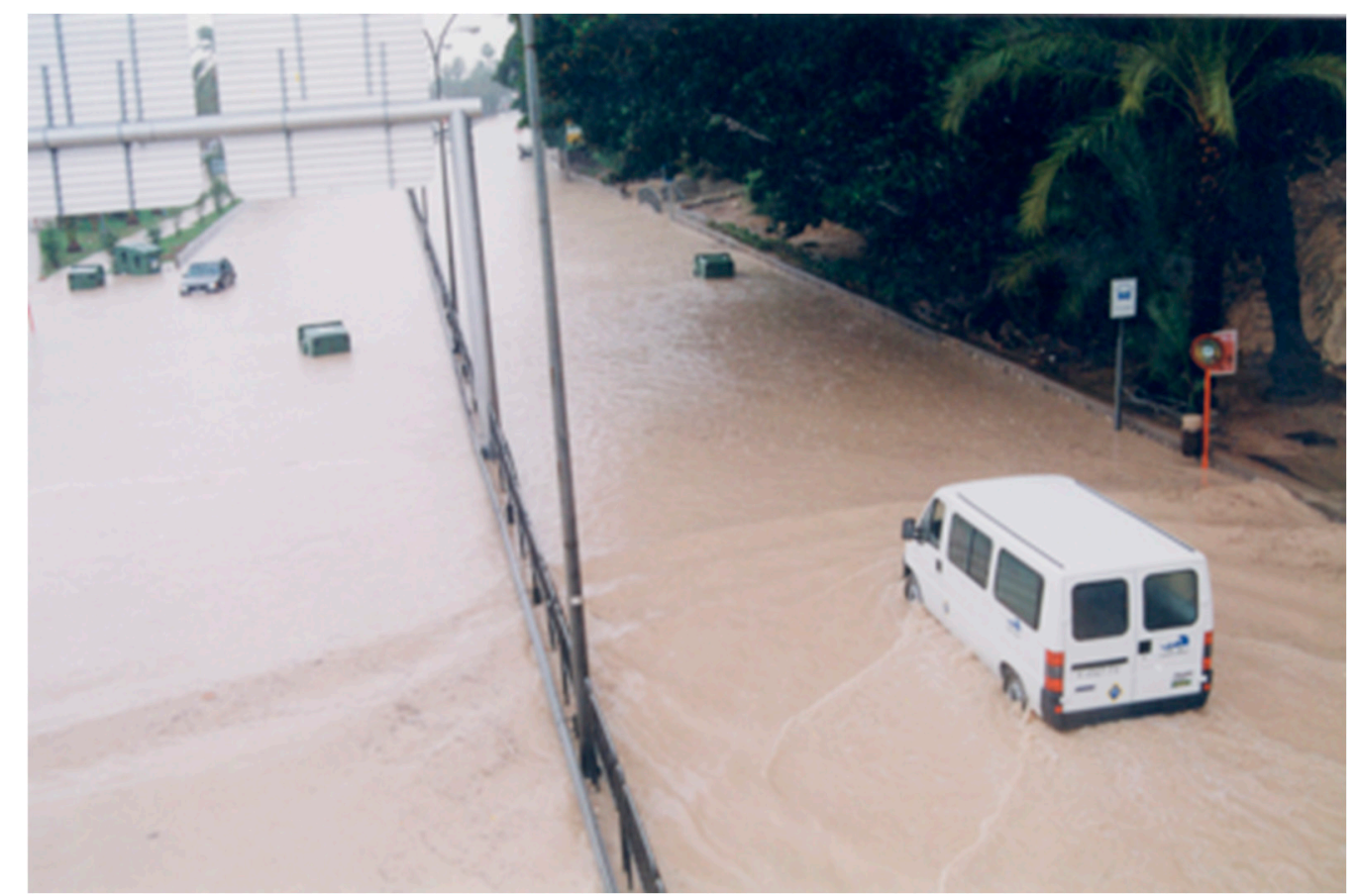

Figure 3. Flooding of Denia Avenue due to the overflowing of the Bonhivern ravine (29 September 1997). Source: Authors.

The city of Alicante has a storm drainage network of 113,000 km (separated from the wastewater drainage system). It accounts for $17 \%$ of the total drainage network. This is slightly lower than the average percentage in Spain, which is 24\% [62] (p. 6). Another non-negligible matter is the fact that the stormwater in this separate system often ends up in general water collectors leading to the collapse of the network in situations of heavy rainfall.

Within this context, we should also add the two actions undertaken by AMAEM with respect to the storage of stormwater, the José Manuel Obrero Díez Anti-pollution Tank and the La Marjal Floodplain Park (Figure 4). The objectives of the anti-pollution tank are: (1) to reduce the pollution of the first runoffs with a high pollutant load that circulate through the permeable areas of the city; and (2) to thereby prevent their discharge into the sea. The objective of the La Marjal Floodplain Park is to resolve the flooding problems in the urban sector called "Alicante Golf". 


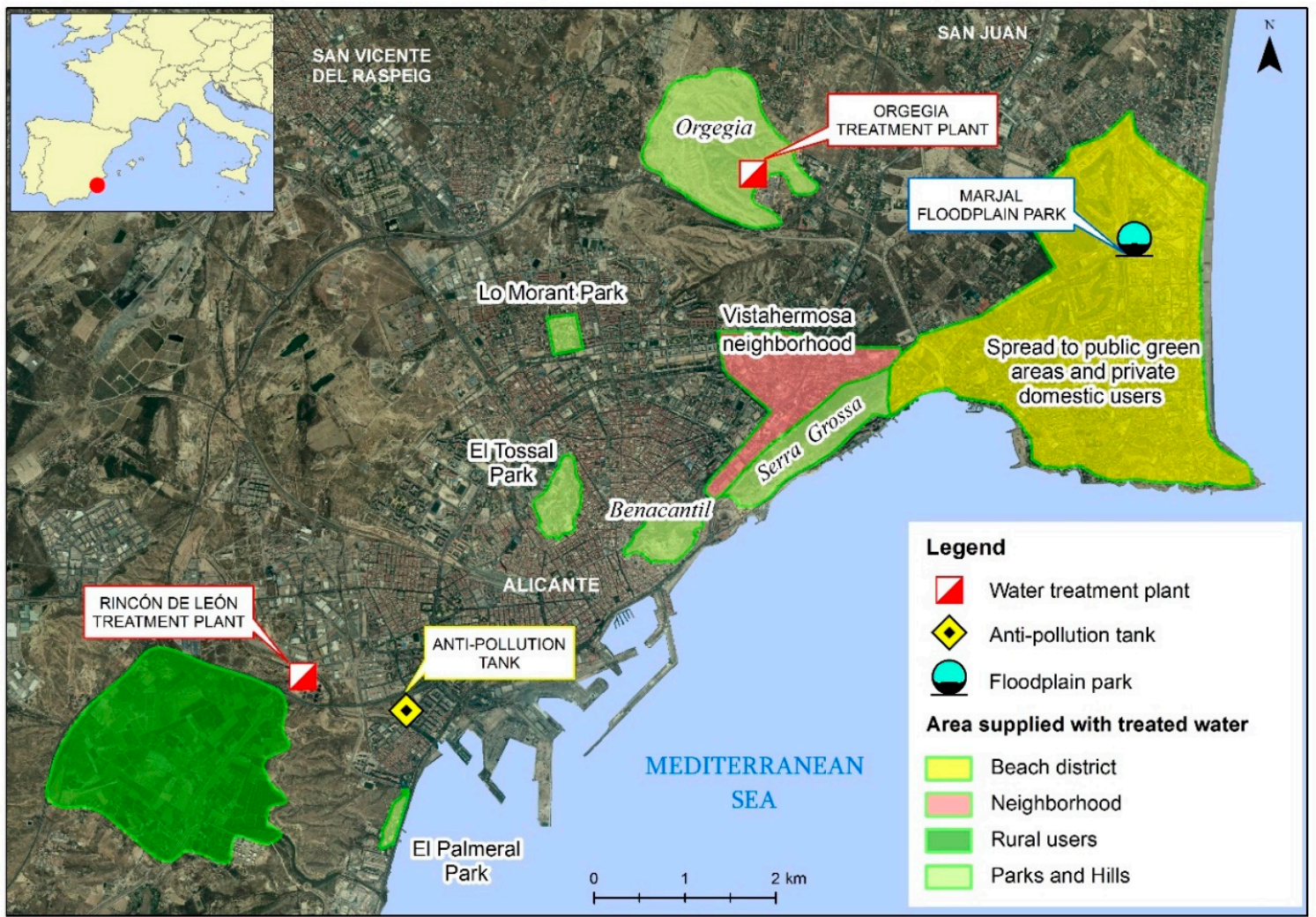

Figure 4. Location of the stormwater infrastructures and green areas watered with treated water. Own elaboration.

The first of these infrastructures has a maximum storage volume of $60,000 \mathrm{~m}^{3}$. This unit has operated several times since it was completed in May 2011 (Figure 5). This has primarily been in the late summer months and, to a lesser degree, in the spring, which highlights the rainfall pattern that is characteristic of the south-east part of the peninsula. This tank, which collects the first runoffs of approximately $50 \%$ of the urban area of the city, can be practically filled in barely $30 \mathrm{~min}$ with a rainfall of $30 \mathrm{~L} / \mathrm{h}$. The torrentiality of the rains, concentrated in a few annual episodes, is reflected in the highly prominent peaks in certain months and years (Table 2) such as, for example, April $2013\left(148,060 \mathrm{~m}^{3}\right)$ or December $2016\left(170,432 \mathrm{~m}^{3}\right)$. By way of example, we can refer to the storms of the 19th and 20th October 2016, when $58,416 \mathrm{~m}^{3}$ were stored, of which $31,434 \mathrm{~m}^{3}$ were accumulated after the storm of 20th October when $21.2 \mathrm{~L} / \mathrm{m}^{2}$ were collected in a little over half an hour. Specifically, worth mentioning is the year 2019, when four heavy rainfalls events gave rise to the storage of over $100,000 \mathrm{~m}^{3}$, the highest number in the whole series, which corroborates the increase in the torrentiality of the rains. 


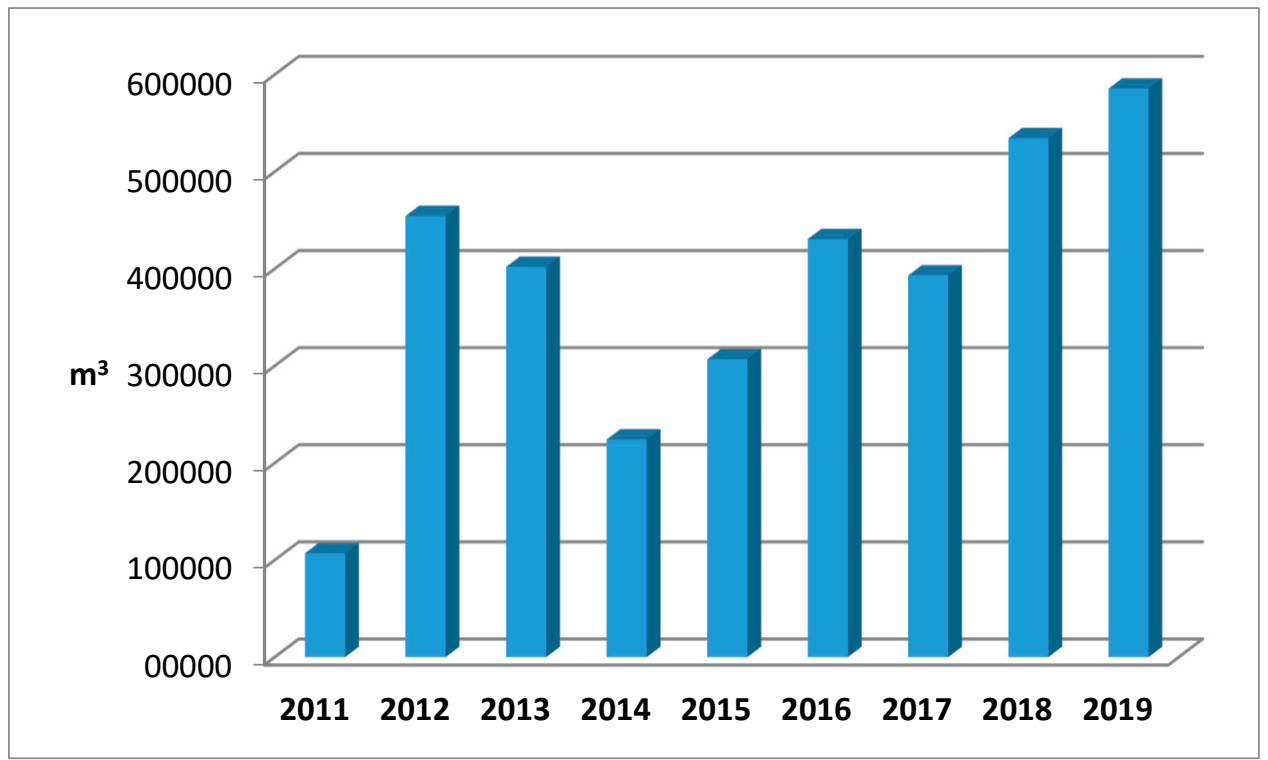

Figure 5. Evolution of the volume of water stored monthly in the José Manuel Obrero Díez Anti-Pollution Tank (2011-2019). Source: [42]. Own elaboration.

Table 2. Evolution of stored rainwater in the José Manuel Obrero Díez Anti-Pollution Tank (2011-2019) $\left(\mathrm{m}^{3}\right)$.

\begin{tabular}{cccccccccc}
\hline & $\mathbf{2 0 1 1}$ & $\mathbf{2 0 1 2}$ & $\mathbf{2 0 1 3}$ & $\mathbf{2 0 1 4}$ & $\mathbf{2 0 1 5}$ & $\mathbf{2 0 1 6}$ & $\mathbf{2 0 1 7}$ & $\mathbf{2 0 1 8}$ & $\mathbf{2 0 1 9}$ \\
\hline January & 0 & 32,428 & 20,586 & 0 & 0 & 19,051 & 95,681 & 69,500 & 23,420 \\
February & 0 & 10,418 & 20,718 & 0 & 0 & 0 & 11,440 & 60,430 & 0 \\
March & 0 & 59,944 & 14,611 & 0 & 24,891 & 21,989 & $\mathbf{6 4 , 4 4 6}$ & 12,987 & 0 \\
April & 0 & 25,905 & 148,068 & 1162 & 36,577 & 26,513 & $\mathbf{6 6 7 9}$ & $\mathbf{2 7 , 4 8 6}$ & 135,580 \\
May & 0 & 0 & 17,247 & 2863 & 0 & 17,875 & 1200 & 0 & 0 \\
June & 0 & 6433 & 0 & 0 & 10,060 & 0 & 0 & 68,801 & 0 \\
July & 0 & 0 & 0 & 0 & 0 & 5040 & 32,310 & 0 & 0 \\
August & 0 & 0 & 76,768 & 9620 & 0 & 0 & 66,857 & 20,775 & 111,200 \\
September & 0 & 65,395 & 0 & 52,818 & 98,496 & 0 & 60,000 & 69,960 & 126,734 \\
October & 20,400 & 108,209 & 0 & 29,084 & 76,726 & 83,390 & 39,579 & 142,037 & 80,000 \\
November & $\mathbf{6 2 , 2 1 4}$ & 145,651 & 16,793 & 76,500 & 60,000 & 86,263 & 15,000 & 50,657 & 108,600 \\
December & 24,380 & 0 & 87,170 & 52,115 & 0 & 170,432 & 0 & 11,824 & 0 \\
Total & $\mathbf{1 0 6 , 9 9 4}$ & $\mathbf{4 5 4 , 3 8 3}$ & $\mathbf{4 0 1 , 9 6 1}$ & $\mathbf{2 2 4 , 1 6 2}$ & $\mathbf{3 0 6 , 7 5 0}$ & $\mathbf{4 3 0 , 5 5 3}$ & $\mathbf{3 9 3 , 1 9 2}$ & $\mathbf{5 3 4 , 4 5 7}$ & $\mathbf{5 8 5 , 5 3 4}$ \\
\hline
\end{tabular}

Source: [42]. Own elaboration.

The second infrastructure is the La Marjal Floodplain Park (opened in April 2015). Its recreational purpose (a recreational area with landscape features and a design that replicates a marshland-Mediterranean wetland-) is complemented by its role in mitigating flood risk. Being located in an endorheic area, it acts as a reservoir with a capacity of 45,000 $\mathrm{m}^{3}$ and a flood level of 5.60 metres (Figure 6). Its construction (together with two large collectors) seeks to resolve the recurrent flooding problems in the lower part of Avenue Pintor Pérez Gil (urbanisation Alicante Golf-Hoyo 1). Once the water is stored, there is a possibility of sending it to the Monte Orgegia water treatment plant (4 km away) for its subsequent reuse (see Figure 4 ). Since it was opened, it has been operational on several times (Table 3). In October 2016, after the storms of the 19th and 20th October, it accumulated $3000 \mathrm{~m}^{3}$. During the episode of 13 March 2017, (150 L between 19.30 and 22.00) it reached 15,500 $\mathrm{m}^{3}$; the highest volume since it was built. This amount was surpassed after the storms of 20 August 2019 when, according to the AEMET, $86.8 \mathrm{~L}$ per square metre were recorded, 41.2 of which in only one hour [40]. The volumes stored in this infrastructure (Figure 7) partly mitigated the damage generated by these precipitations in the nearby urbanised area. 


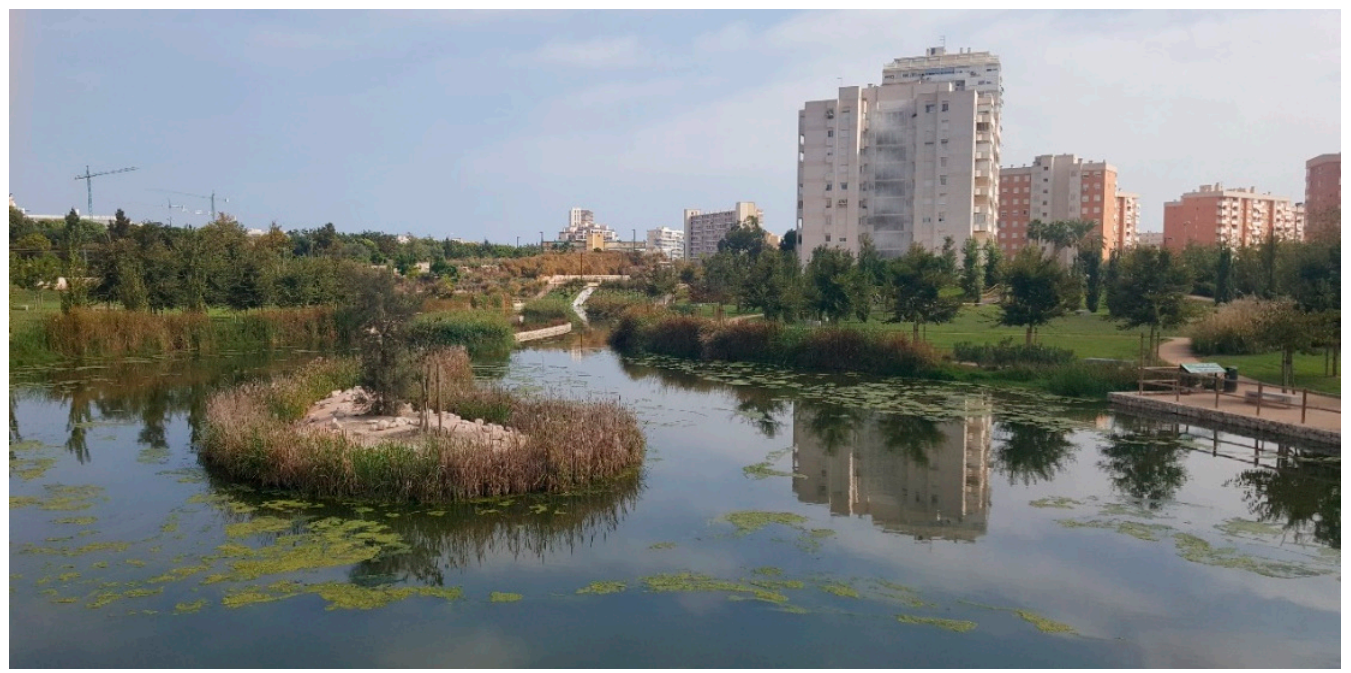

Figure 6. La Marjal Floodplain Park. Source: Authors.

Table 3. Evolution of stored rainwater in La Marjal Floodplain Park (2015-2019) $\left(\mathrm{m}^{3}\right)$.

\begin{tabular}{cccccc}
\hline & $\mathbf{2 0 1 5}$ & $\mathbf{2 0 1 6}$ & $\mathbf{2 0 1 7}$ & $\mathbf{2 0 1 8}$ & $\mathbf{2 0 1 9}$ \\
\hline January & 0 & 0 & 600 & 0 & 0 \\
February & 0 & 0 & 0 & 0 & 0 \\
March & 0 & 0 & 15,500 & 0 & 0 \\
April & 0 & 0 & 0 & 0 & 1500 \\
May & 0 & 0 & 0 & 0 & 0 \\
June & 0 & 0 & 0 & 600 & 0 \\
July & 0 & 0 & 0 & 0 & 0 \\
August & 0 & 0 & 2000 & 0 & 22,000 \\
September & 0 & 0 & 0 & 0 & 500 \\
October & 2000 & 3000 & 0 & 0 & 0 \\
November & 1500 & 0 & 0 & 1500 & 0 \\
December & 0 & 1500 & 0 & 0 & 0 \\
Total & $\mathbf{3 5 0 0}$ & $\mathbf{4 5 0 0}$ & $\mathbf{1 8 , 1 0 0}$ & $\mathbf{2 1 0 0}$ & $\mathbf{2 4 , 0 0 0}$ \\
\hline
\end{tabular}

Source: [42]. Own elaboration.
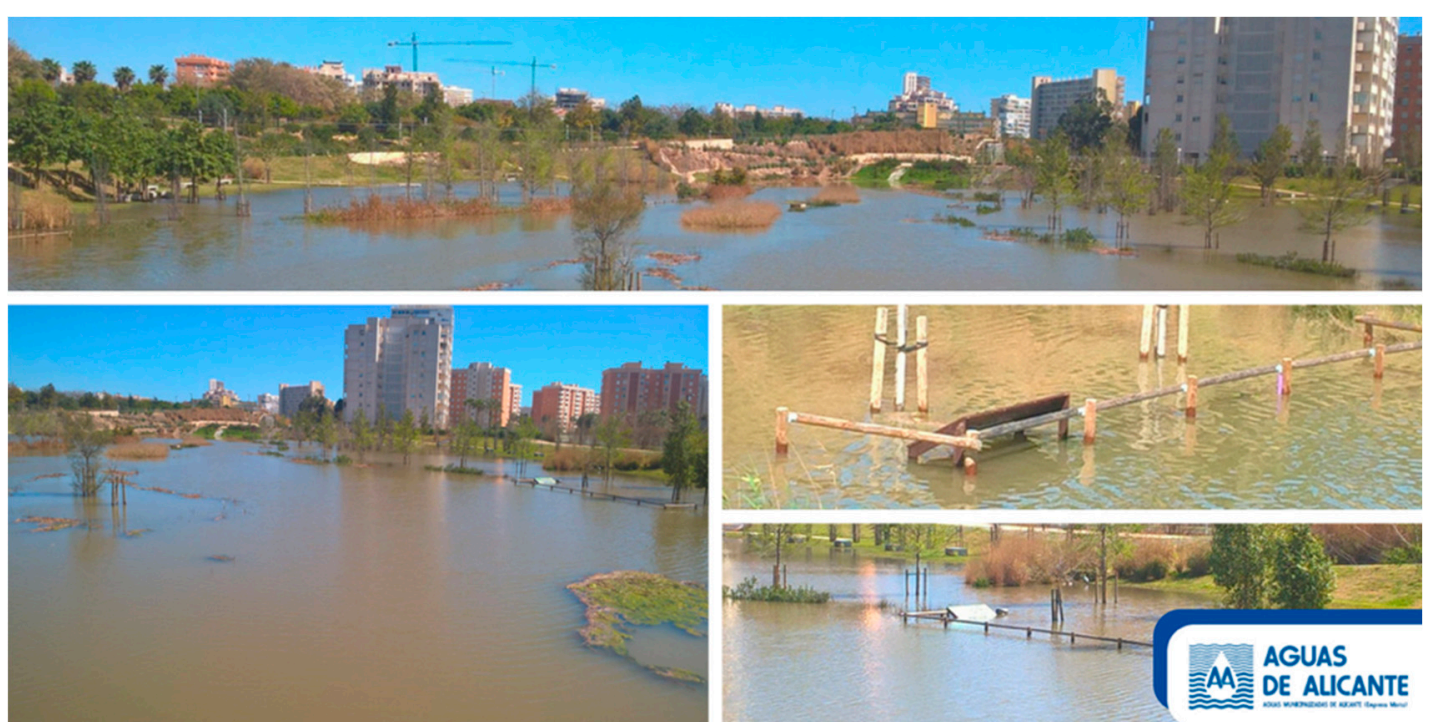

Figure 7. La Marjal Floodplain Park flooded after the rain episodes of 21 August 2019. Source: [42]. 
The construction of the two infrastructures takes part of the Master Plan for the Reuse of Treated Water approved by the water supplying company. One of the objectives of the plan is a progressive replacement of drinking water with reclaimed treated water for watering green areas and street cleaning (see Figure 4). The double reused water network waters $446 \mathrm{Ha}$. of parks and gardens, that is, around $80 \%$ of the green areas of the city.

\subsection{Proposal for Future Actions within a Context of Adapting to Climate Change}

As a future proposal for the management of stormwater in the city of Alicante, a comprehensive system should be developed that includes the construction of seven new rainwater tanks (Figure 8). From south to north: (1) a tank in the urban sector of Benalúa Sur-Puerto de Alicante, beside the Casa Mediterráneo, to harvest rainwater that frequently floods the National Road 332; (2) another tank in the San Blas-Santo Domingo neighbourhood for harvesting rainwater from the ravine with the same name; (3) a third tank in the Spain Square (Spain square tank) to collect superficial flows from the Canicia ravine (city centre) which the anti-flooding works are not able to channel; (4) another under the car park of Postiguet beach to harvest rainwater that is stored in Avenue of Denia from the overflowing of the Bonhivern ravine; (5) a fifth tank in the Colonia Romana area (La Albufereta) in order to collect the small overflows of the Maldo Ravine; (6) another under the park of Avenue. Miriam Blasco (beach sector), given that it is an area that frequently gets waterlogged (endorheic area); and (7) a final tank in San Juan beach (Figures 9 and 10).

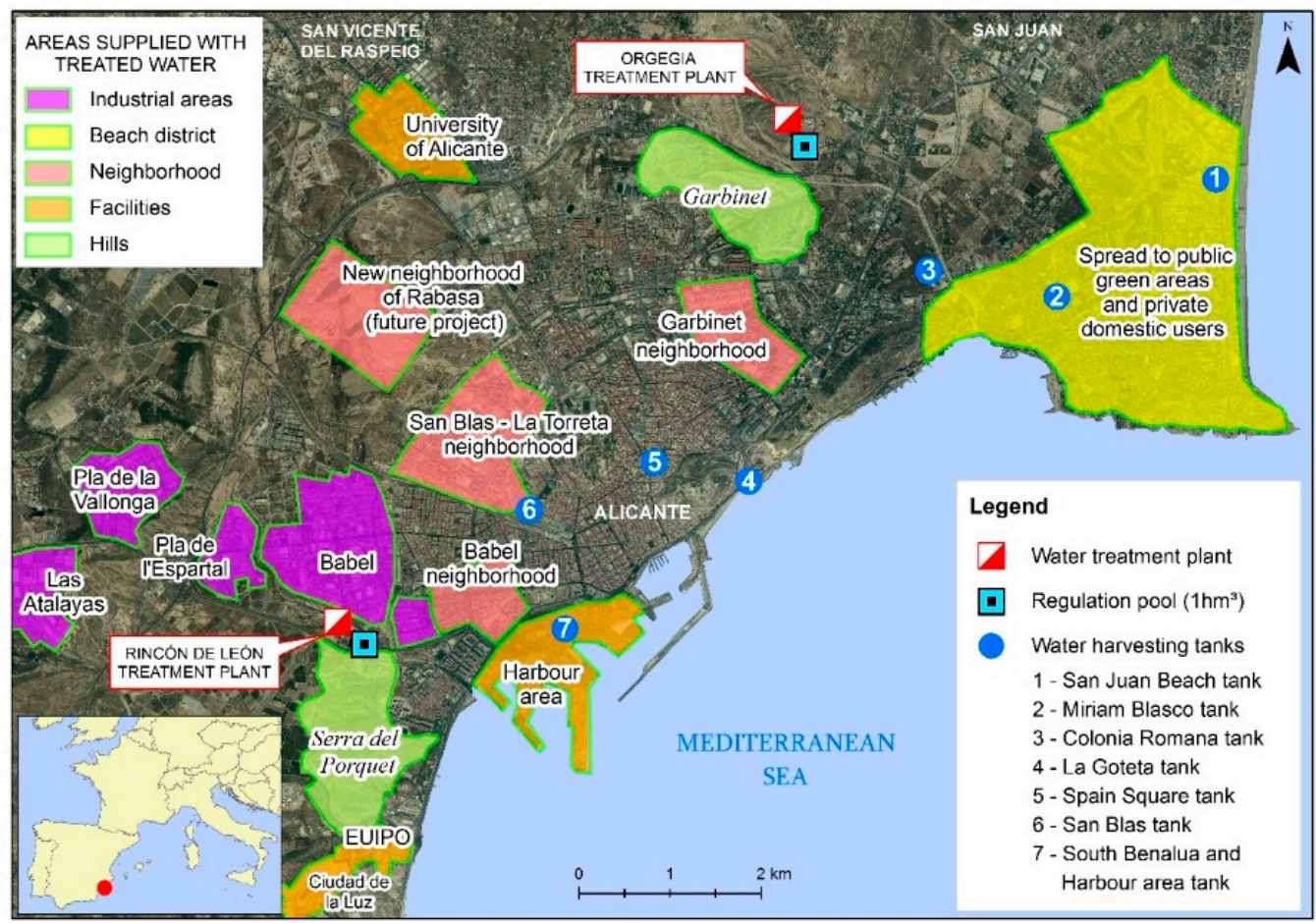

Figure 8. Proposals of infrastructures for harvesting and storing stormwater in the destination areas. Own Elaboration. 


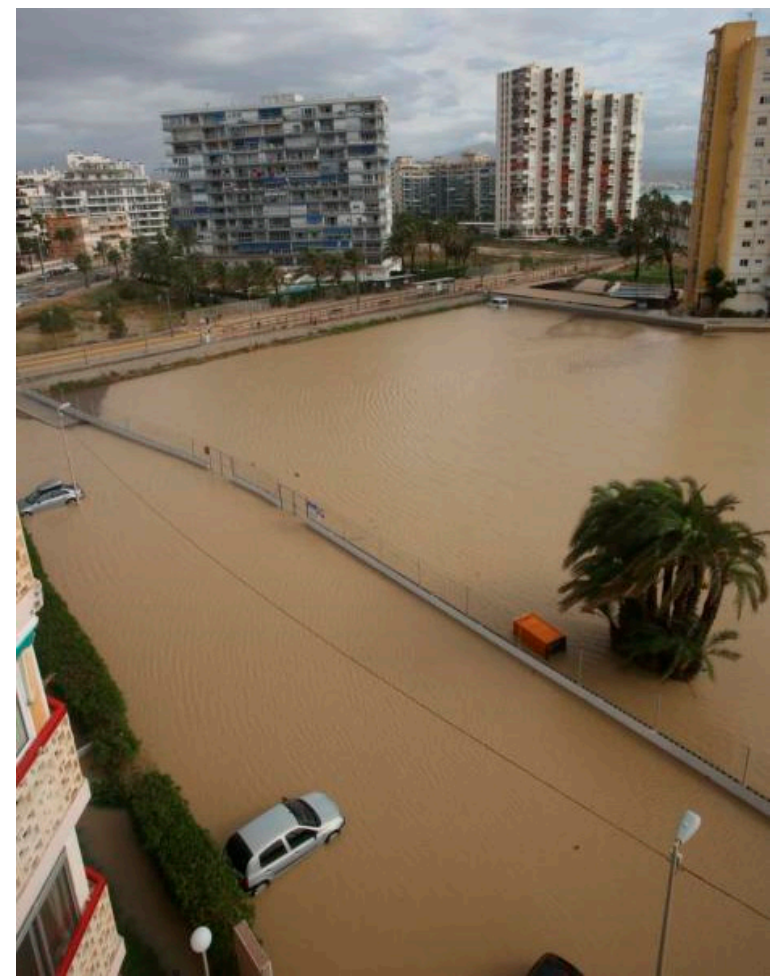

Figure 9. Old floodable area in San Juan Beach that has been urbanised since the 1960s. Note: episode of the 21 of August 2019. Source: [63].

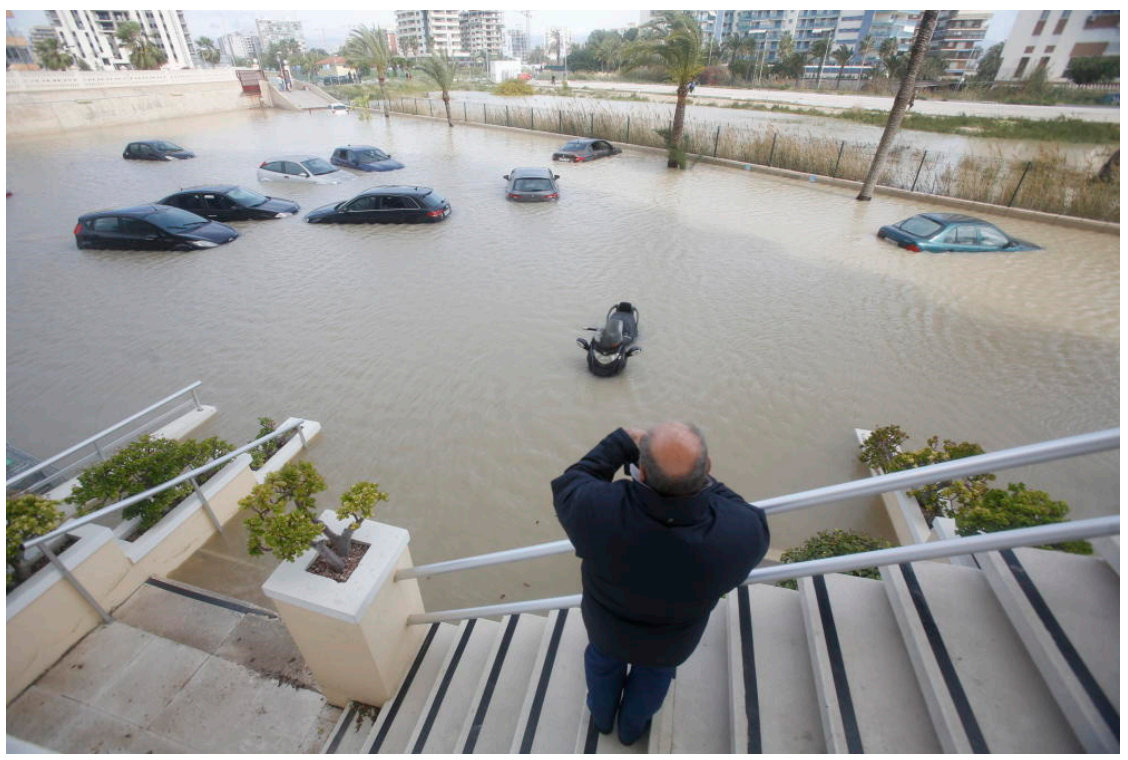

Figure 10. Flooded parking of one blocks of apartments in San Juan Beach. Note: episode of the 21 August of 2019. Source: [63].

All of these tanks should be connected with the city's two water treatment plants, and subsequently, with the treated water distribution system so that it may be used once suitably treated. In this way, not only is the effect of the waterlogging associated with rainfall of a certain hourly intensity mitigated, but the pressure on drinking water for non-consumptive uses is also reduced. For example, non-domestic uses such as the watering of gardens and green areas (both public and private) and street cleaning could increase the areas potentially benefiting from these resources. To do this, it would be necessary not only to construct these units, but also facilities to store the water once treated 
(approximately $1 \mathrm{hm}^{3}$ each) close to the two treatment plants. Furthermore, the distribution network of these resources would also need to be extended (see Figure 8).

The capacity of each of these new tanks should be around $60,000 \mathrm{~m}^{3}$. Therefore, together with the two already existing infrastructures, the maximum capacity in the city would be 525,000 $\mathrm{m}^{3}$. Taking into account that the average annual volume of water stored in the anti-pollution tank (2011-2019) is $416,000 \mathrm{~m}^{3}$, with a total capacity of $525,000 \mathrm{~m}^{3}$, a volume of $3.6 \mathrm{hm}^{3}$ could be harvested each year (triple the volume of treated water that is currently used in the city of Alicante). In relation to the potential of these waters in the city of Alicante, it is worth mentioning that they have been incorporated into the hydrosocial cycle over the last two decades with the implementation of the Master Plan for the Reuse of Treated Water in 2002. In this initial year, the volume amounted to $39,358 \mathrm{~m}^{3}$, while in 2017 it had risen to $1,141,556 \mathrm{~m}^{3}$. In other words, $4.79 \%$ of the total drinking water supplied to the city.

\section{Discussion}

Adapting to climate change is one of the major challenges of societies on a global scale [28]. In Spain, according to forecasting models, the effects of global warming on climate conditions will be manifested in a decrease in the volume of rainfall and an increase in their variability in terms of time and space [30]. Some regions, such as the Mediterranean coastline will be particularly sensitive to the effects of these changes in rainfall patterns $[64,65]$. This is due both to the natural scarcity of rainfall and a demand for water that increased significantly in the last two decades of the twentieth century. However, consumption, at least in urban areas, has moderated and even reduced since the middle of the last decade [66].

As previously indicated, the rainfall in Alicante has decreased by $12 \%$ in the last international climate period (1980-2010) with respect to the previous one (1960-1990) [67]. Meanwhile, the number of days of rain shows a decreasing trend since 1980, calculated as a reduction of $10 \%$ between 1980 and 2010 [45]. These are trends that confirm the climate modelling at the end of the century [48] for Spain [68], but also for the Mediterranean basin [69,70]. Marcos and Pulido [35] calculate a reduction of $20 \%$ in the runoff of flows of the watercourses for the whole of the territory of the Jucar water basin (within which the area of study is located).

At the same time, different studies highlight that the average speed of the Polar Jet Stream will have reduced by $14 \%$ since 1980 [71]. This means a greater undulation of the jet stream, that is, the more frequent generation of planetary waves (peaks and valleys) with faster displacements of hot air masses towards northern latitudes and polar or arctic air towards the south. Muñoz et al. [54] show that 20\% of the increase in cold front atmospheric situations happens in mid-planetary latitudes. The increase in the superficial temperature of the Mediterranean Sea is also evident. Pastor et al. [57] point to an increase of $1.2^{\circ} \mathrm{C}$ in the western Mediterranean. The current climate of Alicante, on the Spanish Mediterranean coastline, has been experiencing highly significant alterations in temperatures and rainfall over the last three decades [67].

The importance of stormwater as a non-conventional resource is even more marked, if possible, if we take into account the consequences of climate change and adapting to it, which is one of the greatest challenges of societies on a global level [28]. Mitigation policies have been focused towards new forms of diversifying water sources through the use of non-conventional resources (for example, the use of stormwater) and towards planning and management of water resources increasingly focused on demand management. These policies also have the purpose of mitigating risks through sustainable development initiatives [72]. This new approach, together with the regulatory changes (specifically the passing of the Water Framework Directive 2000/60/EC), is not unrelated to the recent situations of drought and water shortages in the Mediterranean basin and Iberian Peninsula, which are difficult to address with conventional resources alone. The emergence of desalination as an alternative and, at the same time, its controversial efficiency due to the high costs, the lack of demand for this resource and its capacity to generate situations of relative scarcity for certain sectors (irrigated agriculture or the more 
modest urban social strata) have determined the emergence of new resources such as treated reclaimed water and stormwater [7].

In Spain, strategies are beginning to be developed to adapt to climate change and the associated atmospheric extremes. These strategies contemplate both structural measures (adaptation works, actions related to energy and water supply), and non-structural measures (spatial planning). Within this context, particularly noteworthy are Barcelona, Málaga, Alicante, Reus, Calviá, and different municipalities in the Basque Country where municipal by-laws have been passed concerned with reducing the effects of climate change [73]. In the case of adapting to floods in the urban areas, the actions carried out on an international level and in Spain are related to the development of rainwater harvesting systems to reduce water flows circulating through the streets (rainwater harvesting units), improvements in urban drainage systems to adapt them to the more intense flows (SUDs) or the construction of rainwater storage spaces as recreational areas (floodable parks) such as in Santiago de Chile or Vitoria-Gasteiz and Alicante in Spain [39].

The growing interest in this type of infrastructure is reflected in numerous initiatives aimed at encouraging green infrastructure. Three projects in different phases of execution are worth mentioning in the province of Alicante, namely, the floodplains in San Juan, Elche, and Benidorm. They are intended to trap the initial circulating flows coinciding with heavy rainfall, reduce flooding processes, avoid polluting discharges into the sea, and create new green areas. The Benidorm project has been selected within the Urban Innovative Actions initiative of the European Union. This growing interest in these types of infrastructures has given rise to the proposal of new actions in the city of Alicante developed in this study. Specifically, in the city of Alicante, seven new tanks are proposed which, together with the two existing ones, will increase the storage capacity to $500,000 \mathrm{~m}^{3}$. This is similar to the volume available in the city of Barcelona in 2020, although there it is distributed among 12 tanks [12]. One fact that illustrates the interest in these water resources is that the water supplying company (AMAEM) is planning to extend the areas to which it supplies treated reclaimed water for watering gardens in the metropolitan area of Alicante. The potential areas to receive this water are, in addition to the city of Alicante for urban use (street cleaning, watering public and private green areas), the golf courses in the surrounding municipalities. In other words, the two golf courses existing in the city and municipal area and that of Plantío (Monforte de Cid, located $20 \mathrm{~km}$ away). These strictly urban uses could be complemented with the use of these treated resources for irrigating the nearby agricultural areas (Bacarot, Rebolledo, San Vicente del Raspeig, Sant Joan, Mutxamel, and El Campello).

The use of alternative water resources, such as rainwater, has different advantages. First, the harvesting and storage of rainwater enables the urban streets to be drained and avoids the flooding of certain urban areas [74]. In this respect, authors such as Campisano et al. [75] acknowledge that these practices as an efficient tool for mitigating superficial runoff.

Second, it increases the supply of water to the city and replaces certain uses that previously relied on drinking water. The two main infrastructures of the city of Alicante, as we have seen, are clear examples of an adaptation to climate change phenomena as they: (1) mitigate the effects of flooding; and (2) use rainwater. With respect to the second, this has enabled a reduction in the dependency on other resources such as those from the Tagus-Segura Aqueduct (TSA) and desalination. In the case of the latter, the main problem is a high cost, while that for the TSA is its socio-political controversy that constitutes an obstacle for its use [76]. In this way, a complementary resource is obtained for certain uses that do not require a high quality (watering of gardens, street cleaning, etc.). Its use is related to the so-called "fit for purpose" concept enabling the pressure on other water resources (more expensive, more scarce, and of a higher quality) to be reduced. Morote et al. [37] calculate that in a detached house, the consumption of drinking water decreased by 54\% between 2007 and 2013 from 2300 to $1052 \mathrm{~L} / \mathrm{home} /$ day, thanks, largely, to the use of treated water for irrigating gardened areas. One of the reasons underlying its use is its lower cost. Although it is a free resource (rainwater), there is a certain level of cost involved in maintaining the infrastructures and treating it. Morote and Hernández [6] 
noted that, once integrated with treated reclaimed water, its cost amounts to $0.32 € / \mathrm{m}^{3}$, as opposed to the $1.69 € / \mathrm{m}^{3}$ of drinking water. This price can be compared to that of other resources, for example, that of desalination. In the area of study, the use of desalination has led to an increase in the price of water in recent years [61]. This is the case, for example, of the water supplied during 2015 and 2016 from the Muchamiel plant to the Water Consortium of the Marina Baja (province of Alicante). This supply entailed an increase of $27.7 \%$, rising from 0.36 to $0.46 € / \mathrm{m}^{3}$.

Third, with the harvesting of rainwater the pollutant load on urban road surfaces is collected and, therefore, the pollution of the evacuation zones is avoided (either urban or natural areas) [77]. As revealed by this study, in the city of Alicante it is important to maintain the quality of the sea water at a high level due to the sun and beach tourism activity. The stormwater that is collected in the city has a high pollutant load. Therefore, it should be treated in treatment plants and subsequently integrated with the treated water for both domestic and non-domestic uses. We should also remember that the different forms of rainwater harvesting have enabled the creation of green spaces in the city, for example, gardened areas, public parks, or green roofs. This has led to the creation of new leisure and recreational spaces for citizens, so necessary in urban spaces, which is currently being made evident with the Covid-19 pandemic. In the case of the city of Alicante, the Marjal Floodplain Park, as well as being a park, is an example for raising awareness and disseminating information about flood risks (environmental education) through school outings [78]. To these actions, we should also add the green roof in the new building of the Environmental Sustainability Observatory of the City Council of Alicante or the green facade of the new town hall of San Vicente.

\section{Conclusions}

This study seeks to show that the use and exploitation of stormwater can be beneficial for creating more sustainable cities with natural resources, better adapted to the future scenarios of climate change. Currently, though incipiently, we are witnessing a change of paradigm in the local management of rainwater. In the city of Alicante rainwater is shifting from being seen as a risk to being considered as a resource. In other words, a "rediscovery of this resource" is taking place, as indicated by Hernández and Morote [39], with future perspectives for adapting to the new socio-environmental and climate challenges. Specifically, and as a result of the effects of heavy rains event and the new proposals for more sustainable water management, two rainwater tanks have been built by the city's water supply company (Aguas Municipalizadas de Alicante, Empresa Mixta, AMAEM, Alicante, Spain). It is also proposed to build 7 new rainwater tanks to, on the one hand, to reduce the effects of heavy rainfall and, on the other, to increase water resources given the impact that drought episodes have on them. Both issues must be taken into account in urban planning given the effects of climate change in this study area.

To sum up, assessing the advantages and disadvantages of this resource, according to the most comprehensive and sustainable proposals for managing demand, rainwater will, in the near future, probably become a resource with greater prominence in urban environments with scarce water resources. In the city of Alicante, the use of reclaimed water for garden irrigation has been carried out since 1997. Its use has increased in recent years. Its use is part of the so-called circular economy whose objective is to reduce the pressure on water resources. Therefore, a better knowledge of the characteristics of these resources, of their uses, management systems and their potential would represent a clear step forward towards a more sustainable and resilient planning model to address the possible effects of climate change. This is one of the future lines of research derived from this paper. This would be complemented with other lines related to advancing the knowledge regarding its economic feasibility, how the population perceives its use, which is, whether they are in favour or opposed to its use, or the actions to adopt in the urban architecture and in homes in order to implement its use.

Author Contributions: Conceptualization, methodology, formal analysis, writing-original draft preparation and writing-review and editing: Á.-F.M., M.H.-H. and J.O. All authors have read and agreed to the published version of the manuscript. 
Funding: The results presented in this paper are part of the research's projects "Uses and Management of Non-Conventional Water Resources on the Coast of Valencia and Murcia as an Adaptation Strategy to Drought" funded by the Spanish MINECO under grant number CSO2015-65182-C2-2-P and "Social representations of school content in the development of teaching competencies" funded by the Spanish MINECO under grant number PGC2018-094491-B-C32. In the same way, this work has been funded partially by the Cátedra del Agua of the University of Alicante and the Diputación Provincial de Alicante (https://catedradelaguaua.org/).

Acknowledgments: The authors would like to thank Aguas Municipalizadas de Alicante, Empresa Mixta S.A. for providing the data about rainwater harvesting, and especially Asunción Martínez, Francisco Bartual, Francisco Agulló, César Vázquez, Vicent Martínez, and Antonio Sánchez, and the schools that participated.

Conflicts of Interest: The authors declare no conflict of interest.

\section{References}

1. Hernandez, M.; Morote, A.F.; Moltó, E. El secano mejorado y la agricultura aterrazada. Paisajes significativos con un gran valor socio-ambiental y didáctico. Erebea 2019, 4, 161-188. [CrossRef]

2. Morales, A.; Hernández, M. Aproximación epistemológica sobre los usos de agua de avenida en las laderas subáridas. In Ciencia Regional y Andalucía a partir de la visión del geógrafo Gabriel Marco Cano García. Un homenaje a su vida y obra; Marquez Domínguez, J.A., Borrel, R.M.J., Eds.; Editorial Servicio de Publicaciones de la Universidad de Sevilla: Sevilla, Spain, 2018; pp. 279-288.

3. Palerm, J. Antología Sobre Pequeño Riego. Sistemas de Riego no Convencionales; Colegio de Postgraduados: Montecillo, Mexico, 2002; Volume 3, pp. 1-17.

4. Moltó, E.; Hernández, M. La subexplotación de los paisajes culturales y su incidencia en los riesgos naturales. Una propuesta metodológica. In Investigando en Rural; Baena, R., Foronda, C., Galindo, L., García, A., García, A.M., García, B., Guerrero, I., Navarro, L., Prados, M.J., Posada, J.C., Eds.; Asociación de Geógrafos Españoles: Sevilla, Spain, 2012; pp. 483-491.

5. Marco, J.A.; Morales, A. Terrazas de cultivo abandonadas en el sureste peninsular: Aspectos evolutivos. Investig. Geográficas 1995, 13, 81-90. [CrossRef]

6. Morote, A.F.; Hernández, M. El uso de aguas pluviales en la ciudad de Alicante. De Viejas ideas a nuevos enfoques. Pap. Geogr. 2017, 63, 7-25.

7. Hernández, M.; Saurí, D.; Moltó, E. Las aguas pluviales y de tormenta: Del abandono de un recurso hídrico con finalidad agrícola a su implantación como recurso no convencional en ámbitos urbanos. In Paisaje, Cultura Territorial y Vivencia de la Geografía. Libro Homenaje al Profesor Alfredo Morales Gil; Vera, J.F., Olcina, J., Hernández, M., Eds.; Servicio de Publicaciones de la Universidad de Alicante: Alicante, Spain, 2016; pp. 1.099-1.120.

8. Burriel, E. La década prodigiosa del urbanismo español (1997-2006). Scr. Nova 2008, 270. Available online: http://www.ub.es/geocrit/sn/sn-270/sn-270-64.htm (accessed on 10 August 2020).

9. Morote, A.F.; Olcina, J.; Hernández, M. The use of non-conventional water resources as a means of adaptation to drought and climate change in semi-arid regions: South-Eastern Spain. Water 2019, 11, 93. [CrossRef]

10. Swyngedouw, E. Liquid Power. Water and Contested Modernities in Spain. 1998-2010; The Mit Press: Cambridge, MA, USA, 2015.

11. Vallès, M.; March, H.; Saurí, D. Decentralized and user-led approaches to rainwater harvesting and greywater recycling: The case of Sant Cugat del Vallès, Barcelona, Spain. Built Environ. 2016, 42, 243-257. [CrossRef]

12. Nóblega, A.; Saurí, D.; March, H. Community involvement in the implementation of Sustainable Urban Drainage Systems (SUDs): The case of Bon Pastor, Barcelona. Sustainability 2020, 12, 510. [CrossRef]

13. Wang, M.H.; Ho, Y.S.; Fu, H.Z. Global performance and development on sustainable city based on natural science and social science research: A bibliometric analysis. Sci. Total. Environ. 2019, 666, 1245-1254. [CrossRef]

14. Jamali, B.; Bach, P.M.; Deletic, A. Rainwater harvesting for urban flood management-An integrated modelling framework. Water Res. 2020, 171, 115372. [CrossRef]

15. Prokop, G.; Jobstmann, H.; Schönbauer, A. Overview on Best Practices for Limiting Soil Sealing and Mitigating Its Effects in EU-27; Environment Agency Austria: Vienna, Austria, 2011.

16. Rodríguez, M.I. El agua y la ciudad de hoy. Equip. Y Serv. Munic. 2005, 117, 18-38. 
17. Shun Chan, F.K.; Griffiths, J.A.; Higgitt, D.; Xu, S.; Zhu, F.; Tang, Y.T.; Xu, Y.; Thorne, C.R. "Sponge City" in China. A breakthrough of planning and flood risk management in the urban context. Land Use Policy 2018, 76, 772-778. [CrossRef]

18. Suleiman, L.; Olofsson, B.; Saurí, D.; Palua-Rof, L. A breakthrough in urban rain-harvesting schemes through planning for urban greening: Case studies from Stockholm and Barcelona. Urban. Urban. Gree. 2020, 51, 126678. [CrossRef]

19. Bashar, M.Z.I.; Karim, M.R.; Imteaz, M.A. Reliability and economic analysis of urban rainwater harvesting: A comparative study within six major cities of Bangladesh. Resourc. Conserv. Recy. 2018, 133, 146-154. [CrossRef]

20. Sedlak, D. Water 4.0: The Past, Present and Future of the World's Most Vital Resource; Yale University Press: New Haven, CT, USA, 2014.

21. Imteaz, M.A.; Moniruzzaman, M. Spatial variability of reasonable government rebates for rainwater tank installations: A case study for Sydney. Resour. Conserv Recycl. 2018, 133, 112-119. [CrossRef]

22. Paudel, U.; Imteaz, M.A.; Matos, C. Equations for potential water savings through rainwater harvesting for different climatic conditions in Adelaide (Australia). Int. J. Hydrol. Sci. Technol. 2018, 8, 91-104. [CrossRef]

23. Domènech, L.; March, H.; Saurí, D. Degrowth initiatives in the urban water sector? A social multi-criteria evaluation of non-conventional water alternatives in Metropolitan Barcelona. J. Clean Prod. 2013, 38, 44-55. [CrossRef]

24. Jing, X.; Zhang, S.; Zhang, J.; Wang, Y.; Wang, Y. Assessing efficiency and economic viability of rainwater harvesting systems for meeting non-potable water demands in four climatic zones of China. Resour Conserv. Recy. 2017, 126, 74-85. [CrossRef]

25. Lopes, V.A.R.; Marques, G.F.; Dornelles, F.; Medellin-Azuara, J. Performance of rainwater harvesting systems under scenarios of non-potable water demand and roof area typologies using a stochastic approach. J. Clean Prod. 2017, 148, 304-313. [CrossRef]

26. Ursino, N.; Grisi, A. Reliability and efficiency of rainwater harvesting systems under different climatic and operational scenarios. Int. J. Sustain. Dev. Plan. 2017, 12, 194-199. [CrossRef]

27. Hopkins, K.; Bhaskar, A.; Woznicki, S.A.; Fanelli, R.M. Changes in event-based streamflow magnitude and timing after suburban development with infiltration-based stormwater management. Hydrol. Process. 2019, 1-17. [CrossRef]

28. Intergovernmental Panel on Climate Change [IPCC]. Special Report on Global Warming of $1.5^{\circ} \mathrm{C}$. Contribution of Working Group I to the Fifth Assesment Report of the Intergovernmental Panel on Climate Change (AR5). 2018. Available online: https://www.ipcc.ch/sr15/ (accessed on 3 May 2020).

29. Intergovernmental Panel on Climate Change [IPCC]. Special Report on Climate Change, Desertification, Land Degradation, Sustainable Land Management, Food Security, and Greenhouse gas fluxes in Terrestrial Ecosystems. In Contribution of Working Group I to the Fifth Assesment Report of the Intergovernmental Panel on Climate Change (AR5); Intergovernmental Panel on Climate Change [IPCC]: Geneva, Switzerland, 2018. Available online: https://www.ipcc.ch/report/srccl/ (accessed on 4 May 2020).

30. Gallego, M.C.; Trigo, R.M.; Vaquero, J.M.; Brunet, M.; García, J.A.; Sigró, J.; Valente, M.A. Trends in frequency indices of daily precipitation over the Iberian Peninsula during the last century. J. Geoph. Res. 2011, 116. [CrossRef]

31. Miró, J.J.; Estrela, M.J.; Olcina, J. Reconstrucción de la señal térmica local en la Comunidad Valenciana entre 1948 y 2011 a partir de un downscaling estadístico mediante una red neuronal artificial: Detección de patrones locales de cambio. Boletín Asoc. Geógrafos Españoles 2016, 70, 113-147.

32. Sauri, D.; Olcina, J.; March, H.; Martín-Vide, J.; Vera, J.F.; Padilla, E.; Serra-Llobet, A. Tourism, Climate Change and Water Resources: Coastal Mediterranean Spain as an Example. In European Climate Vulnerabilities and Adaptation: A Spatial Planning Perspective; Schmidt-Thomé, P.H., Greiving, S., Eds.; John Wiley \& Sons, Ltd.: Hoboken, NJ, USA, 2013; pp. 231-252.

33. Monjo, R.; Martín-Vide, J. Daily precipitation concentration around the world according to several indices. Int. J. Clim. 2016, 36, 3828-3838. [CrossRef]

34. Vicente-Serrano, S.; Azorín-Molina, C.; Peña-Gallardo, M.; Tomas-Burguera, M.; Domínguez-Castro, F.; Martín-Hernández, N.; Beguería, S.; Kenawy, A.E.; Noguera, I.; García, M. A high-resolution spatial assessment of the impacts of drought variability on vegetation activity in Spain from 1981 to 2015. Nat. Hazards Earth Syst. Sci. 2019, 19, 1189-1213. [CrossRef] 
35. Marcos-García, P.; Pulido-Velázquez, M. Cambio climático y planificación hidrológica: ¿Es adecuado asumir un porcentaje único de reducción de aportaciones para toda la demarcación? Ing. Del Agua 2017, 21, 35-52. [CrossRef]

36. Vargas, M.V.; Rovira, M.R.; Gabarrell, X.; Villalba, G. Cost-effective rainwater harvesting system in the Metropolitan Area of Barcelona. J. Water Supply Res. Technol. 2014, 63, 586-595. [CrossRef]

37. Morote, A.F.; Hernández, M.; Rico, A.M. Causes of Domestic Water Consumption Trends in the City of Alicante: Exploring the Links between the Housing Bubble, the Types of Housing and the Socio-Economic Factors. Water 2016, 8, 374. [CrossRef]

38. Morote, A.F.; Olcina, J.; Rico, A.M. Challenges and Proposals for Socio-Ecological Sustainability of the Tagus-Segura Aqueduct (Spain) under Climate Change. Sustainability 2017, 9, 2058. [CrossRef]

39. Hernández, M.; Morote, A. The use of rainwater (Southeast Spain). A new urban approach to urban water management. UPLanD 2019, 4, 53-66.

40. Agencia Estatatal de Meteorología [AEMET]. Datos Abiertos. AEMET Open Data. 2019. Available online: http://www.aemet.es/es/datos_abiertos/AEMET_OpenData (accessed on 27 April 2020).

41. Agencia Valenciana de Meteorología [AVAMET]. Estadísticas y Meteored Fechas históricas. 2019. Available online: https://www.avamet.org/mx-meteoxarxa.php (accessed on 27 April 2020).

42. Aguas Municipalizadas de Alicante, Empresa Mixta (AMAEM). Datos Sobre Consumo de Agua; AMAEM: Alicante, Spain, 2019.

43. De Luis, M.; Brunetti, M.; Gonzalez-Hidalgo, J.C.; Longares, L.A.; Martin-Vide, J. Changes in seasonal precipitation in the Iberian Peninsula during 1946-2005. Glob. Planet. Chang. 2010, 74, 27-33. [CrossRef]

44. Miró, J. Downscaling Estadístico de Series Climáticas Mediante Redes Neuronales: Reconstrucción en alta Resolución de la Temperatura Diaria Para la Comunidad Valenciana. Interpolación Espacial y Análisis de Tendencias (1948-2011). Ph.D. Thesis, Universidad de Alicante, Alicante, Spain, 2014. [CrossRef]

45. Serrano, R. Reconstrucción Climática Instrumental de la Precipitación Diaria en España: Ensayo Metodológico y Aplicaciones. Ph.D. Thesis, Universidad de Zaragoza, Zaragoza, Spain, 2017.

46. Olcina, J. Incremento de episodios de inundación por lluvias de intensidad horaria en el sector central del litoral mediterráneo español: Análisis de tendencias en Alicante. Semata 2017, 29, 143-163.

47. Agencia Estatal de Meteorología [AEMET]. Atlas Climático Ibérico; Ministerio de Medio Ambiente y Medio Rural y Marino: Madrid, Spain, 2019.

48. Centro de Estudios y Experimentación de Obras Públicas [CEDEX]. Evaluación del Impacto del Cambio Climático en los Recursos Hídricos y Sequías en España; Ministerio de Agricultura y Pesca, Alimentación y Medio Ambiente y Ministerio de Fomento: Madrid, Spain, 2017.

49. Agencia Estatal de Meteorología [AEMET]. Proyecciones Climáticas Para el Siglo XXI en España. 2019. Available online: http://www.aemet.es/es/serviciosclimaticos/cambio_climat (accessed on 27 January 2020).

50. Instituto Geológico y Minero [IGME] y Diputación Provincial de Alicante. Atlas Hidrogeológico de la Provincia de Alicante. 2015. Available online: https://ciclohidrico.com/descargas/documentos/ (accessed on 2 May 2020).

51. Confederación Hidrográfica del Júcar [CHJ]. Plan. Hidrológico de la Cuenca del Jucar, 2021-2027. Available online: https://www.chj.es/es-es/medioambiente/planificacionhidrologica/Paginas/PHC-2021-2027-Indice. aspx (accessed on 30 April 2020).

52. Millán, M.; Estrela, M.J.; Miró, J.J. Rainfall components: Variability and spatial distribution in a Mediterranean area (Valencia region). J. Clim. 2005, 18, 2682-2705. [CrossRef]

53. Confederación Hidrográfica del Segura. Cronología de Riadas en la Cuenca del río Segura (1259-2012). Available online: https://www.chsegura.es/chs/informaciongeneral/elorganismo/unpocodehistoria/riadas. html (accessed on 27 January 2020).

54. Muñoz, C.; Schultz, D.; Vaughan, G. A Midlatitude Climatology and Interannual Variability of 200- and 500-hPa Cut-Off Lows. J. Clim. 2020, 33, 2201-2222. [CrossRef]

55. Biener, S. Confirmado, las DANAs Están Aumentando de Forma Notable en Europa. Tiempo.com. 20 February 2020. Available online: https://www.tiempo.com/noticias/actualidad/gotas-frias-danas-son-mas-habitualesdesde-1960-espana.html (accessed on 28 April 2020).

56. Pastor, F.; Valiente, J.J.; Khodayar, S. A Warming Mediterranean: 38 Years of Increasing Sea Surface Temperature. Remote Sens. 2020, 12, 2687. [CrossRef]

57. Pastor, F.; Valiente, J.A.; Palau, J.L. Sea Surface Temperature in the Mediterranean: Trends and Spatial Patterns (1982-2016). Pure Appl. Geophys. 2018, 175, 4017-4029. [CrossRef] 
58. Agencia Estatal de Meteorología [AEMET]. Informe sobre el estado del clima de España 2019; Ministerio para la Transición Ecológica y el Reto Demográfico. Madrid, 2020. Available online: http://www.aemet.es/documentos/es/conocermas/recursos_en_linea/publicaciones_y_estudios/ estudios/Informes\%20estado\%20clima/Informe_estado_clima_2019.pdf (accessed on 25 August 2020).

59. Confederación Hidrográfica del Jucár [CHJ. Plan. Especial de Sequía. Available online: https://www.chj.es/ Descargas/ProyectosOPH/RevisionPES/memoriaPES.pdf (accessed on 5 May 2020).

60. Olcina, J.; Moltó, E. Climas y Tiempos del País Valenciano; Publicaciones de la Universidad de Alicante: Alicante, Spain, 2019.

61. Morote, A.F.; Olcina, J.; Rico, A.M.; Hernández, M. Water Management in Urban Sprawl typologies in the City of Alicante (Southern Spain): New Trends and Perception after the Economic Crisis? Urban. Sci. 2019, 3, 7. [CrossRef]

62. Asociación Española de Abastecimientos de Agua y Saneamiento [AEAS]. Informe Sobre Aguas Residuales en España. Dia Mundial del Agua, 2017. Available online: https://www.asoaeas.com/sites/default/files/ Documentos/Informe\%20sobre\%20aguas\%20residuales\%20AEAS.pdf (accessed on 27 April 2020).

63. Diario Información. Available online: https://www.diarioinformacion.com/multimedia/videos/alicante/201908-21-181911-lluvia-deja-aparcamientos-playa-juan-inundados-coches-bloqueados.html (accessed on 21 August 2019).

64. Benhamrouche, A.; Martín Vide, F.J. Avances metodológicos en el análisis de la concentración diaria de la precipitación en la España peninsular. An. Geogr. Univ. Complut. 2012, 32, 11-27. [CrossRef]

65. Ribas, A.; Olcina, J.; Saurí, D. More exposed but also more vulnerable? Climate change, high intensity precipitation events and flooding in Mediterranean Spain. Disaster. Prev. Manag. 2020, 29, 229-248. [CrossRef]

66. Gil, A.; Hernández, M.; Morote, A.F.; Rico, A.M.; Saurí, D.; March, H. Tendencias del consumo de agua potable en la ciudad de Alicante y Área Metropolitana de Barcelona, 2007-2013; Hidraqua, Gestión Integral de Aguas de Levante, S.A. y Universidad de Alicante: Alicante, Spain, 2015.

67. Olcina, J. Clima, cambio climático y riesgos climáticos en el litoral mediterráneo. Oportunidades para la geografía. DAG 2020, 66, 159-182. [CrossRef]

68. Serrano, R.; Martin-Vide, J.; Saz, M.A.; Longares, L.A.; Beguería, S.; Sarricolea, P.; Meseguer-Ruiz, O.; De Luis, M. Spatio-temporal variability of daily precipitation concentration in Spain based on a high-resolution gridded data set. Int. J. Climatol. 2018, 38, 518-530. [CrossRef]

69. Benabdelouahab, T.; Gadouali, F.; Boudhar, A.; Lebrini, Y.; Hadria, R.; Salhi, A. Analysis and trends of rainfall amounts and extreme events in the Western Mediterranean region. Theor. Appl. Climatol. 2020, 141, 309-320. [CrossRef]

70. Mathbout, S.; Lopez-Bustins, J.A.; Royé, D.; Martin-Vide, J.; Benhamrouche, A. Spatiotemporal variability of daily precipitation concentration and its relationship to teleconnection patterns over the Mediterranean during 1975-2015. Int. J. Climatol. 2020, 40, 1435-1455. [CrossRef]

71. Martín, F. Los Inviernos Serán Más Cálidos, Pero También con Irrupciones Más Frías. Revista del Aficionado a la Meteorología 2019. Available online: https://www.tiempo.com/ram/507091/los-inviernos-seran-mascalidos-pero-tambien-con-irrupciones-mas-frias/ (accessed on 3 May 2020).

72. Cramer, W.; Guiot, J.; Fader, M.; Garrabou, J.; Gattuso, J.P.; Iglesias, A.; Lange, M.A.; Lionello, P.; Llasat, M.C.; $\mathrm{Paz}, \mathrm{S}$; ; et al. Climate change and interconnected risks to sustainable development in the Mediterranean. Nat. Clim. Chang. 2018, 8, 972-980. [CrossRef]

73. Morote, A.F.; Rico, A.M.; Moltó, E. Critical review of desalination in Spain: A resource for the future? Geogr. Res. 2017, 1-12. [CrossRef]

74. Jato-Espino, D.; Charlesworth, S.M.; Bayon, J.R.; Warwick, F. Rainfall-runoff simulations to assess the potential of suds for mitigating flooding in highly urbanized catchments. Int. J. Environ. Res. Public Health 2016, 13, 149. [CrossRef]

75. Campisano, A.; Gnecco, I.; Modica, C.; Palla, A. Designing domestic rainwater harvesting systems under different climatic regimes in Italy. Water Sci. Technol. 2013, 67, 2511-2518. [CrossRef]

76. Morote, A.F.; Hernández, M.; Rico, A.M.; Eslamian, S. Inter-basin water transfer conflicts. The case of the Tagus-Segura Aqueduct (Spain). Int. J. Hydrol. Sci. Technol. 2020, 10, 364-391. [CrossRef]

77. Sales-Ortells, H.; Medema, G. Microbial health risks associated with exposure to stormwater in a water plaza. Water Res. 2015, 74, 34-46. [CrossRef] 
78. Morote, A.F. El Parque Inundable La Marjal de Alicante (España) como propuesta didáctica para la interpretación de los espacios de riesgo de inundación. Didáctica Geográfica 2017, 18, 211-230.

(C) 2020 by the authors. Licensee MDPI, Basel, Switzerland. This article is an open access article distributed under the terms and conditions of the Creative Commons Attribution (CC BY) license (http://creativecommons.org/licenses/by/4.0/). 